\title{
Fenômeno e conflito: Sexto contra Porchat
}

\author{
Vítor Hirschbruch Schvartz \\ USP / Colégio Marista Glória
}

\section{RESUMO}

A leitura da obra de Sexto Empírico que Porchat nos legou apresenta uma inovadora interpretação do conceito cético de phainómenon. Tal interpretação explicitou, ao contrário do que comumente é feito, o enorme alcance e largo escopo de tal conceito, sem, contudo, subtrair do pirronismo boa parte do radicalismo típico de uma filosofia sem crenças. O fenômeno, ou "aquilo que aparece", é o critério de ação do ceticismo, após a conhecida suspensão do juízo sobre tudo. Ele desempenha também, não obstante, um curioso papel no conflito de ideias que levava o pirrônico grego à equipolência e à consequente retenção do assentimento, ao contribuir frequentemente, segundo o próprio Sexto Empírico, para um dos lados de algumas das disputas mais essenciais da História da Filosofia, como a da querela com o imobilismo. Tal aspecto da noçáo de phainómenon pode apontar para um lado curioso e um tanto anacrônico da filosofia sextiana que, náo notado por Porchat, nos apresenta uma figura do cético bastante diferente da do neopirrônico contemporâneo: alguém profundamente impactado filosoficamente tanto pela metafísica quanto por aquilo que aparece.

\begin{abstract}
Opposing the original Skeptic as portrayed by Sextus Empiricus to Oswaldo Porchat's Neopyrrhonist, the paper aims to show the essential difference between the two, especially in regard to the notion of phainómenon. Porchat offered a brilliant and innovative interpretation of Sextus, but failed to realize a somewhat anachronistic aspect of the notion of "the apparent": it is part of the conflict that leads the skeptic to suspension of judgment and it impacts the skeptic not only psychologically, but also philosophically. The outcome is that the Ancient Skepticism, unlike Neopyrrhonism, is as much an outcome of examining dogmatic and metaphysical discourse as of contemplating the apparent things.
\end{abstract}

\section{KEY WORDS}

Skepticism; Sextus Empiricus; Oswaldo Porchat.

\section{PALAVRAS-CHAVE}

Ceticismo; Sexto Empírico;

Oswaldo Porchat. 


\section{A obediência cética aos fenômenos}

Heidegger abre "Ser e tempo" se queixando do fato de que nosso tempo se tem por

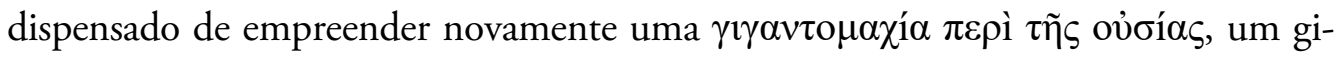
gantomaquia sobre o ser, curiosa maneira com a qual o Estrangeiro de Eléia descreve, para seu interlocutor Teeteto, o tipo de investigação filosófica na qual ambos estavam imersos no Sofista (p. 246). Pretendo discutir o ceticismo de Oswaldo Porchat à luz do que interpreto como sendo o pirronismo de Sexto Empírico, filósofo que inspirou o brasileiro mesmo décadas antes de que ele viesse a se confessar um neopirrônico. Pretendo, em verdade, opor a figura do cético sextiano àquela do neopirrônico porchatiano. Se o último sempre pareceu avesso à filosofia especulativa de um Heidegger ou Hegel, por exemplo, me pergunto, de outro lado, qual seria a postura de uma atualização ortodoxa do ceticismo sextiano perante a afirmação Heideggeriana da necessidade de uma repetiçáo explícita da questão do ser, frase de abertura de "Ser e tempo". Me pergunto sobre se o pirronismo antigo náo poderia inspirar uma prática (dýnamis) cética bastante diferente do tipo de postura filosófica que encontramos no neopirronismo. Me parece que tal atualização ortodoxa teria de dar mais ênfase do que deu o neopirronismo à alegada suspensão do juizo sobre tudo, a famosa epokhé peri pánthon de Sexto Empírico, o que possivelmente levaria a figura desse pirrônico, a título de exemplo, a uma suspensão do juízo sobre a necessidade ou não de se empreender novamente uma gigantomaquia sobre o ser; enquanto o neopirronismo frequentemente parece avesso até mesmo à contemplação da questão. Provocaçôes à parte, antes de colocar em conflito essas duas figuras céticas, a do ortodoxo sextiano, tal como eu o entendo, de um lado, e a do neopirrônico porchatiano, pretendo explorar alguns aspectos do ceticismo de Sexto Empírico de maneira a subsidiar a comparação e fazer jus à enorme contribuição que Porchat deu tanto à compreensão do pirronismo quanto à construção de uma filosofia brasileira.

Há no pirronismo grego o que eu chamo de uma "obediência" cética ao fenômeno, inspirado em algumas passagens de Sexto Empírico. Como é sabido, o phainómenon é o critério de ação do cético grego, é o que sobra após a radical suspensão do juízo sobre tudo, mas cuja interpretação ainda é motivo de controvérsia. Uma maneira de entender a adesão cética aos phainómena é encontrar nela uma forma de crença que estaria permitida ao pirrônico. Em HP I, 229-230, encontramos Sexto Empírico comparando sua filosofia com a filosofia da Nova Academia e dizendo que ambas dizem acreditar (peithestai) em algumas coisas, mas que no caso do pirronismo, trata-se de um acreditar sem inclinação ou propensão forte, como se diz acreditar o menino em seu tutor. Mas o verbo grego "peithesthai" tem vários sentidos, como o de "fiar-se" e também o de "obedecer", e talvez tenha sido tão somente 
esse amplo escopo semântico que tenha permitido aquela comparação com o ceticismo acadêmico a partir desse verbo. Embora de fato Sexto esteja afirmando que o cético acredita em algumas coisas nessa passagem, penso que se fôssemos tentar abstrair uma noção pirrônica de crença daquela passagem cairíamos em uma espécie de "obedecer" cético, dada a metáfora da criança perante o seu pedagogo. Essa curiosa espécie de crença cética ocorreria apenas naquilo que se impóe, como um adulto sobre uma criança muito jovem, daí a insistência de Sexto em definir o fenômeno como azétetos, isto é, impossível de ser investigado ou questionado - ao que poderia se concluir que o cético questiona tudo quanto possível de ser examinado.

O que faz o cético sextiano, a meu ver, é uma eleição do phainómenon como critério de ação, perante a necessidade de um critério que fosse apenas de ação e não de verossimilhança (ao contrário do caso da filosofia da Nova Academia) ou de escolha propriamente dita. Ele escolhe obedecer, à maneira de uma criança, aos fenômenos, sem inclinação - no que se pode supor que, para Sexto, nos dogmatismos e no ceticismo acadêmico haveria inclinaçóes e propensóes das quais o cético estaria livre. ${ }^{1}$ Boa parte do rico livro I das Hipotiposes dá a impressão de ter sido escrita visando a objeçóes e equívocos na compreensão da postura cética, especialmente acerca dos motivos que poderia ter o cético para realizar uma ação e não outra, mas a adesão cética aos phainómena tem claramente um caráter frio, é pouco comprometida, desprovida de inclinação. Em consonância com a mitigação do verbo peithesthai, ao minimizar a forma pela qual o cético pode "acreditar", a maneira de uma criança, em algumas coisas, há textos nos quais a eleição do que aparece, do fenômeno, como critério de ação aparece acompanhada pela justificativa de que os céticos "não podem permanecer inativos" (cf. HP I, 23, 226-227 e AM VII, 29-30). Importante notar que não se trata aqui de reduzir o critério de açáo cético a meras aparências ou a qualquer tipo de falibilismo: a decisão do cético de obedecer aquilo que aparece não se dá apenas porque o phainómenon é o pouco que sobra após a investigação cética. Ao contrário, é justamente pelo fato de os discursos da filosofia

\footnotetext{
1 Em HP I, I9, Sexto afirma que o fenômeno nos leva a um "assentimento involuntário", o que pareceria contradizer a ideia de "eleiçáo" que estou aqui propondo. Penso, contudo, que Sexto se refere, na passagem em questão, ao caráter manifesto e impositivo através do qual aparecem as coisas que nos aparecem, isto é, o fato de que não temos controle sobre aquilo que aparece, de tal modo que o debate é apenas sobre o que é dito e interpretado do phainómenon (HP I,20). O cético original, tal como descrito por Sexto, faz, contudo, a eleição daquilo que se impõe como critério de ação não porque possa controlar a maneira pela qual as coisas lhe aparecem, mas justamente porque não possui qualquer dogma ou crença que, como estoicos resistindo à dor, por exemplo, seja capaz de eliminar o phainómenon na vida cotidiana. Na ausência de uma interpretaçáo do phainómenon que motive um agir diverso daquele por ele espontaneamente orientado, o cético decide segui-lo, pois ele é o pouco que resta após o ferrenho embate contra os dogmatismos filosófico e comum. Isto não significa que outros céticos que não Enesidemo, Agrippa e Sexto não possam estar menos comprometidos com essa eleiçáo não-dogmática e acabem por cair em pântanos, como teria eventualmente feito Pirro. Agradeço a Marco Zingano e Paulo Faria por apontarem para a necessidade de esclarecer esse ponto.
} 
especulativa serem tão fortes quanto as coisas que nos aparecem da forma mais nítida e impositiva (e que, portanto, se impóem a nós), que eles são capazes de quase arrebatá-las (HP I, 20), exigindo uma eleição dos fenômenos como critério unicamente de ação, e de mais nada. A força do que aparece é rivalizada pela força dos argumentos céticos e dogmáticos conta o que aparece, e somente nessa disputa que o cético, em suspensão total do juízo, decide agir com base no fenômeno. Para entender melhor tal perspectiva sobre o fenomenismo cético, é necessário explorar mais a fundo o impacto filosófico que os fenômenos têm na prática cética.

Do ponto de vista da persuasão, aquilo que aparece não é capaz de formar no cético qualquer dogma, pois nada estabelece, como nada estabelecem também aqueles sofisticados discursos de várias doutrinas filosóficas que questionam tudo quanto aparece, já que estão também em conflito entre si; a própria definiçáo que Sexto dá sobre a prática cética de opor a todo discurso um discurso igual nos lembra que tal oposiçáo se refere à credibilidade ou incredibilidade dos discursos opostos (katà pistin è apistían) (HP I 202). Aliás, também a explicação de epékho, isto é, a comumente pronunciada frase cética "eu suspendo o juízo", é, segundo Sexto, "eu sou incapaz de dizer em qual das alternativas propostas devo acreditar e em qual não devo acreditar". (HP I, I96).

As curiosas observaçóes sextianas sobre a força e a sutileza dos discursos dogmáticos, que foram por vezes interpretadas como uma versão avant la lettre da crítica ao discurso metafísico característica da moderna filosofia da linguagem, à moda do neopirronismo porchatiano, devem, a meu ver, ser compreendidas dentro do contexto de um filósofo grego que é sincera e enormemente impactado pelas teses de filósofos dogmáticos, de Parmênides à Crisipo, de Heráclito à Epicuro e, por que não, a Kant, Hegel e Heidegger, se a cronologia assim tivesse permitido. É assim só que, chegando depois à suspensão do juízo, o cético se sente confortável em ironizar os dogmas, chamando-nos de "ídolos (eídola)" e de "ficçôes" (HPII, 222; HP III, I56; AM VIII, I56-7, por exemplo). É somente contemplando a enorme força de persuasão das filosofias em conflito e não tendo como decidir entre as mais persuasivas, também não podendo as aceitar todas ao mesmo tempo, que ele descreve seus dogmas como ídolos e ficções.

Longe de fazer do fiar-se nos phainómena uma forma mais branda de crença, falível e provisória, esse fiar-se é exatamente o contrário: revela um impacto sincero da diaphonía filosófica no intelecto do cético, que, movido pelas brilhantes argumentaçóes dos mais ousados filósofos especulativos, realmente é tocado pela força de persuasão de suas teses de modo a questionar todas as crenças, das mais básicas às mais complexas. Não há, assim, qualquer inclinação à verdade de qualquer proposição no fenomenismo cético, e portanto não se pode falar propriamente, a meu ver, em uma crença cética. Convencido de que nada pode estabelecer, o cético faz 
da suspensão do juízo uma prática, e acrescenta ao enorme arsenal de argumentos filosóficos os modos de Enesidemo, especialmente desenhados para acabar com qualquer tendência de fiarmo-nos nos fenômenos mais simples e banais da vida cotidiana para formular qualquer crença, mesmo as que frequentemente nem as filosofias mais especulativas chegam a questionar.

Mas como "o phainómenon em toda parte tem força, onde quer que venha", como já dizia Timão, discípulo de Pirro (AM VII, 30), só o legado do gênio filosófico de séculos é capaz de garantir ao cético a isosthéneia e à epokhé sobre tudo, inclusive sobre certas crenças comuns e banais do cotidiano às quais o cético afronta, como parece poder ser abstraído da passagem de AM VII, 27, onde Sexto afirma:

Pois ou será preciso que o grande e solene objeto da vaidade dos dogmáticos seja completamente destruído, se não se descobre nenhum cânon da verdadeira realidade das coisas; ou, ao contrário, que os céticos sejam refutados como presunçosos e afrontadores da crença comum, se algo aparece que seja capaz de guiar-nos para a apreensáo da verdade.

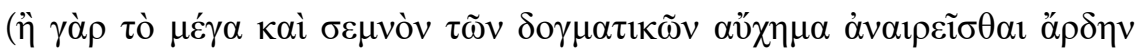

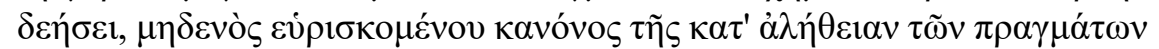

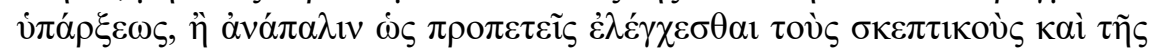

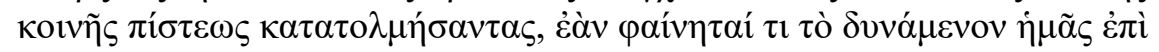

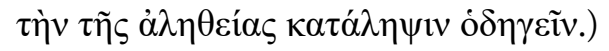

Os céticos são afrontadores da crença comum, vestem essa carapuça! Parte fundamental do legado pirrônico é justamente o combate incessante e por vezes irritante a tudo quanto tendemos a acreditar no dia a dia. Quem conhece os textos de Porchat sabe como essa figura do cético sextiano está longe do neopirrônico.

\section{0 alcance e escopo da noção de phainómenon}

Porchat dedicou um artigo recente ao tema do fenomenismo cético, intitulado "A noção de phainómenon em Sexto Empírico" (Porchat, 20I3). Tal artigo representou o corolário de uma das maiores contribuiçóes de Porchat à compreensão do ceticismo antigo, especialmente no que diz respeito ao alcance e escopo da noção de phainómenon.

Porchat conferiu uma noção mais do que generosa ao phainómenon cético, desde "Sobre o que aparece", o primeiro artigo em que ele assume uma postura filosófica neopirrônica. Seus artigos fundem a mera interpretação histórica da obra sextiana com a formulação de uma postura filosófica própria, e a reconstrução que faz Porchat do conceito cético de phainómenon me parece aproveitável, em boa medida, para a figura do cético sextiano que aqui pretendo apresentar. Afirma Porchat: 
A noção cética de "fenômeno" diz respeito tanto à esfera sensível como à inteligível (no que respeita ao fenômeno inteligível, cf. A.M. VIII 362-3; VII, 336; H.P. I, 4, I5, I9O-I, I97 etc.). E o que aparece, seja sensível ou inteligível, se associa, de um modo geral, a um conteúdo proposicional, exprime-se numa proposição cuja aceitação se nos impóe. Aparece-me que o mel é doce, que o fogo queima, aparece-me que é noite agora, aparece-me que ceticismo e dogmatismo são posturas filosóficas distintas, que faz bastante tempo que Sócrates bebeu a cicuta etc. $\mathrm{E}$ a cada um de nós aparece que muito do que nos aparece também aparece em comum a outros homens. Aparece-nos que o mundo de que fazemos parte se dá a nós e a nossos semelhantes numa experiência comum, isto é, aparece-nos que nossa experiência-de-mundo e as experiênciasde-mundo de outros seres a nós muito semelhantes, os humanos, se interseccionam em larga escala e têm muito de comum. Em A.M. VIII, 8, Sexto nos relata ter Enesidemo (filósofo cético provavelmente do século I A. C., a quem se deve a revivescência da tradição pirrônica) dito que certas coisas aparecem de modo comum (koinôs) a todos, outras aparecem particularmente a alguém. Passagens inúmeras em toda a obra de Sexto assumem esse caráter frequentemente comum dos fenômenos. Por isso, o cético passa espontaneamente do "aparece-me que" ao "aparece-nos que". Podemos dizer que a experiência do "nós" é imediatamente vivida na experiência do fenômeno. A experiência do mundo se nos dá, em bem grande medida, como intersubjetiva. $\mathrm{O}$ ceticismo grego nunca enveredou pelos caminhos do solipsismo, nem mesmo metodológico. (Porchat, 2006, p. 303)

Porchat apontou para o enorme alcance da noção cética de fenômeno, a meu ver afastando a tendência de se interpretar timidamente o fenômeno como sendo "mera" aparência, ou "mera" afecção", ou mesmo o que é "meramente" aparente. O exemplo dos fenômenos coletivos lembrado por Porchat parece em geral ignorado no grande número de trabalhos acerca do ceticismo grego de que dispomos. Creio, entretanto - e isso Porchat não abordou explicitamente - que esse alcance da noção de fenômeno de maneira nenhuma precisa ser entendido como uma diminuição do escopo da epokhé cética. Não nos esqueçamos que o cético sabe, a cada segundo, que o mundo pode ser totalmente diferente do modo como ele lhe aparece, enquanto que as pessoas comuns, de maneira geral, confiam na experiência para formular crenças cotidianas sobre a realidade. Mas uma das descobertas de Porchat acerca de uma visão cética do mundo, perfeitamente aplicável, a meu ver, ao ceticismo de Sexto Empírico, está no fato de que não há solipsismo de nenhuma forma na relação do cético com os fenômenos. Se vários intérpretes do pirronismo, à época da conversão de Porchat ao neopirronismo, já afastavam as interpretações mentalistas e solipsistas, Porchat me parece ter sido o único a enfatizar que não havia privilégio nenhum daquilo que aparece a quem aparece, já que o cético se vê como um item 
dentre vários do mundo. $\mathrm{O}$ fenomenismo cético é fundamentalmente anti-solipsista, já que uma visão de mundo fundamentada no fenômeno parte de uma autoimagem do cético como sendo uma pequena parte de um coletivo, mais um entre outros homens aos quais várias coisas aparecem coletivamente. Esse, inclusive, é o tipo de fenômeno que permite a escrita de um livro introdutório sobre o pirronismo como as Hipotiposes: um autor narrando a experiência filosófica comum a vários céticos para um público que eventualmente poderá experienciar coisas semelhantes.

Tal alcance da noçáo de fenômeno, livre da tendência espontânea que tem o intérprete contemporâneo de restringir seu escopo, deve ser entendido a partir da maneira com a qual o próprio pirrônico explica que chegou a essa peculiar filosofia de suspensão do juízo sobre tudo. Façamos, pois, uma breve e simplificada retrospectiva do itinerário que levou o cético grego à epokhé generalizada: perturbado pela anomalia das coisas e sem saber a quais dar assentimento ele foi buscar, na filosofia, a verdade, mas deparou-se com a discordância geral sobre tudo (inclusive sobre a apreensáo dos objetos externos mais comuns). Essa anomalia, que pode ter começado com dilemas da sua vida profissional, ou ainda sobre assuntos morais, onde os homens frequentemente discordam, algo facilmente notado por um homem propenso a filosofar e com uma certa cultura, parece ter-se expandido para todos os aspectos da vida. Parece ter atingido até mesmo a antes assumida apreensáo dos objetos comuns da experiência, cujo conhecimento é agora posto em questão pelo cético. Se não há por que não pensar, de um lado, que o homem de talento, antes de estudar filosofia, assumia (assim como o restante das pessoas comuns) que apreendia muitas coisas, como sua mesa, seu cachorro etc e achava que tinha delas conhecimento, não há por que, por outro lado, estabelecer qualquer paralelo entre o reconhecimento cético de um phainómenon como a mesa, algo que lhe aparece, com sua crença inicial na existência da mesa. O phainómenon cético é o que resta após o final desse percurso radical de investigação e epokhé, onde o cético adquire a consciência de que, dada a argumentação dos filósofos, qualquer conhecimento sobre os objetos dos nossos sentidos fica bastante complicado.

Faz-se necessário, assim, mitigar um pouco o suposto compartilhamento de fenômenos entre homens comuns, filósofos dogmáticos e filósofos céticos. Os primeiros espontaneamente os hipostasiam, os segundos os interpretam para recusá-los ou reafirmá-los, e os céticos os elegem como critério única e exclusivamente de ação (não de opiniấo, não de persuasão, náo de verdade), numa obediência fria ao que resta após uma radical prática antitética. Por isso penso ser necessário acrescentar à generosa interpretação de Porchat acima mencionada, que somente após essa distinção entre céticos e dogmáticos é que poder-se-ia, talvez, dizer que aparece ao cético que o mesmo fenômeno pode aparecer às três personagens em questão. 


\section{Fenômeno e conflito}

Em 1968 Porchat proferiu a aula inaugural do Departamento de Filosofia da USP de título "O conflito das filosofias", que se tornaria seu primeiro texto publicado com inspiração na leitura, dentre outras, de Sexto Empírico. De viés goldschmidtiano, ele nos apresenta a interessante ideia de um conflito entre filosofias, sofisticando, por assim dizer, a ideia cética antiga de diaphonía. Décadas mais tarde, tendo abandonado a metafilosofia estruturalista, Porchat insistiria na suspensão do juízo como advinda de um conflito entre lógoi, entre discursos opostos, descrevendo adesão neopirrônica aos phainómena como uma recusa dos discursos que interpretavam os fenômenos de maneira dogmática. Cometerei a gafe, irresistível neste caso, de tematizar uma epígrafe, já que a escolhida por Porchat para seu artigo-corolário sobre o fenômeno cético (Porchat, 20I3) diz muito sobre essa sua maneira de ver a questão: "A filosofia é uma investigação do discurso, portanto uma investigação da palavra. (cf. Bruno Schulz, Ficção Completa, p.Io)”. Suspeito que Sexto não comungaria da opiniáo do pintor polonês, como parece apontar uma passagem crucial de Sexto logo do início das Hipotiposes, em HP I, 8, a qual pretendo dar especial atenção como ponto crucial de distanciamento entre pirronismo e neopirronismo:

O ceticismo é uma capacidade de opor coisas que aparecem e coisas inteligíveis de qualquer modo que seja, a partir da qual, devido à equipolência das coisas e discursos opostos, chegamos primeiramente à suspensão de juízo e depois à imperturbabilidade.

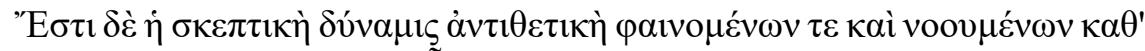

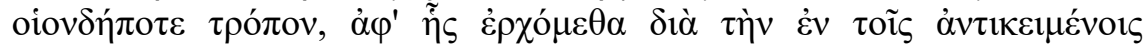

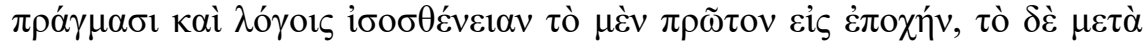

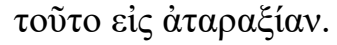

Não é difícil imaginar, para qualquer leitor experiente da obra de Sexto, o que seriam esses discursos opostos a coisas, ou essas coisas que aparecem (tà phainómena) em oposição a pensamentos e discursos. $\mathrm{O}$ debate sobre a existência ou não existência do movimento, por exemplo, tem, do lado do fato de que o movimento aparece, de que o experienciamos, filósofos e homens comuns que confiam no fato de que o movimento é fenômeno. E, do outro lado da polêmica, há alguns filósofos que expressam pensamentos, concebem teses e formulam discursos que nos levam a acreditar que o movimento não existe.

Convencido de que não tem como afirmar nada sobre aquilo que aparece nem o tratar como mera representação, de um lado, tampouco o hipostasiar, de outro - o cético, porém, não tem como negar a força com a qual se manifestam 
para ele várias dessas coisas. Mas a consequência de reconhecer essa força é justamente encontrar a equipolência dela para com a dos discursos filosóficos e confessarse incapaz de acreditar em qualquer coisa, um estado do intelecto bastante distinto daquele em que o neopirrônico diz ter:

$\mathrm{Na}$ medida e no sentido em que nos permitimos dizer que temos crenças, nessa mesma medida e sentido não recusamos ter certezas em nossa vida prática e cotidiana. Náo temos por que hesitar em acolher em nossa linguagem o vocabulário usual da certeza, bastando-nos, também aqui, apenas cuidar para que não se venha sobrepor a nossos usos lingüísticos uma interpretação dogmática, para que deles não se queiram extrair pressupostos epistemológicos ou ontológicos (Porchat, 2006, p.I35)

Não é só no acréscimo de uma interpretação dogmática que a obediência cética à primazia do que aparece, oriunda de uma sincera suspensão do juízo sobre tudo, se diferencia das crenças comuns. O cético recusa as certezas filosóficas ricas em pressupostos ontológicos e epistemológicos, mas recusa também, em sua totalidade, as mais simples certezas das pessoas comuns, distantes de qualquer reflexão filosófica. Não se trata de simplesmente perceber que a maior (ou menor) parte das crenças são dogmáticas: todas as crenças são dogmáticas, refletidas ou não, interpretadas ou interpretáveis. Só assim faz sentido o modo de vida cético alegadamente adoxastós (HP I, 20), sem dóxa. Não pode ser gratuita a escolha de um termo como dóxa, que desde os primórdios da tradiçáo filosófica grega distanciava o filósofo do comum dos homens cheio de opiniôes, para definir a maneira como o cético vive: livre da mera opinião, mas em epokhé. Um caso peculiar de filósofo, mas, antes de tudo, um filósofo.

Sexto Empírico afirma que o pirrônico não "briga por palavras" (phonomakheîn) (HP I, 194-5) e desconfia, assim, da exatidão conceitual almejada por muitos filósofos dogmáticos. Mas por certas palavras, penso, o cético teria de brigar, devido à sua inevitável associação, mesmo que indireta, com a ideia de "verdade".

Confrontemos aquele itinerário cético sextiano com uma ideia presente em vários artigos de Porchat, a metáfora de um philósophos, um estudante de filosofia que, não tendo se convertido a qualquer doutrina filosófica, já não encontra mais, depois de um percurso filosófico, justificação para suas antigas crenças cotidianas. É uma espécie de metáfora de que se serve o discurso neopirrônico de Porchat para introduzir uma peculiar interpretação do pirronismo antigo, segundo a qual o cético seria como um estudante de filosofia que não se converteu a nenhuma doutrina, mas questiona a sua crença na realidade das coisas. Afirmou o autor:

Mas suponhamos também que o nosso jovem filósofo já avançou suficientemente nos seus estudos e reflexão para ter-se dado conta de que não mais pode, diante da visão do mundo do senso comum — como todos, ele dela, por certo, 
em boa medida compartilha —, manter a atitude dogmatizante e pouco crítica do homem ordinário, que por muito tempo foi a sua. Ele aprendeu a problematizar a verdade última das mesmas sentenças que, entretanto, como qualquer um ele cotidianamente profere, ele não tem como conferir-lhes uma efetiva dimensão cognitiva, ele questiona em última análise a relação entre elas e o real, o que quer que isso possa significar. Sua experiência cotidiana, ele não tem ainda como atribuir-lhe qualquer interpretação filosófica. (Porchat, 2006, p. I22)

O âmbito filosófico, para Porchat, parece ser restrito àquele que discute a "verdade última" das coisas, a "dimensão cognitiva" e a relação das crenças com o real. É assim que as doutrinas filosóficas, na explanação pirrônica de Porchat, são precedidas de um "não obstante" (o berkeleyano ou o kantiano teria a mesma crença que um cético ou que um homem comum "apesar de seu imaterialismo" e "não obstante sua doutrina do mundo exterior e da representação", respectivamente (Porchat, 2006, p.I34)). Mas para Sexto Empírico a epokhé radical do pirrônico grego não se limita às interpretaçôes dogmáticas das asserçóes comuns. A prática do pirronismo grego náo se limita a uma investigação da linguagem, mas abrange também as coisas. $\mathrm{O}$ discurso especulativo não é, dessa forma, tão estranho ao cético antigo: é ele quem permite a suspensão do juízo sobre tudo, inclusive sobre os objetos exteriores. A diaphonía filosófica acerca da verdade atinge o cotidiano do filósofo cético, transcende o seu gabinete, e parte fundamental dessa busca por suspensáo do juízo conta com a filosofia especulativa sem ela uma epokhé mais geral seria impossível. O cético não é aquele filósofo que pretendeu problematizar a verdade última das sentenças, é, ao contrário, aquele que problematizou a verdade de toda e qualquer proposição e crença.

\section{Sexto contra Porchat}

O neopirrônismo não depende de uma interpretação correta da filosofia cética, sendo por ela apenas inspirada, em nada ameaçando a coerência e a força da proposta neopirrônica sua mera imprecisão histórica. Mas cabe perguntar também se o velho pirronismo não poderia ser, também ele, fonte de inspiração das reflexôes filosóficas contemporâneas, oferecendo assim uma proposta filosófica de maior afinidade com a tendência contemporânea da valorização das escolas da antiguidade justamente por não terem elas separado suas filosofias, de uma forma ou de outra, da vida comum. Foi o que aventei em "Porchat, sua interpretação de Sexto, e um possível neopirronismo rústico" (Schvartz, 2015). Neste artigo, lembrei que o neopirrônico reclama, aparentemente com razão, da caricatura que foi imposta ao ceticismo durante séculos, por filósofos antigos e modernos. Mas a caricatura que faz o neopirrônico urbano da metafísica, mesmo ao interpretar a obra de Sexto Empírico, não me parece menor. A maneira de se conceber o cético sextiano ortodoxamente atualizado seria imaginar 
alguém bem mais impactado por reflexôes chamadas "metafísicas", alguém não tão descrente no poder do lógos em encontrar verdades quanto o pirrônico urbano. Em sua prática antitética de opor fenômenos e opiniôes, o pirrônico rústico de fato suspende o juízo sobre a proposição "a parede é branca” tanto quanto sobre qualquer outra proposição dogmática, por não reconhecer qualquer privilégio dos sentidos sobre os dogmas filosóficos ou vice-versa. Não haveria, para ele, qualquer privilégio, por exemplo, da proposição "a neve é branca" sobre a proposição "a neve é preta”, por mais que a neve lhe apareça branca naquele momento. Continuei aquela reflexáo convidando o leitor a uma comparação hipotética: um filósofo eleata que, convencido por Parmênides, "sabe" que todas aquelas afirmaçóes sobre objetos externos que fazemos no dia a dia são falsas, não pareceria enfrentar, em geral, as acusaçóes de incoerência com as quais o cético tem de lidar. Tal filósofo eleata hipotético vive uma vida que ele "sabe" ser no mundo da ilusão; ele acredita na falsidade de cada uma daquelas proposiçóes descritivas que utiliza no seu dia a dia. Tal figura me parece muito mais aparentada à de um pirrônico que levou a sério aquelas antigas reflexóes filosóficas, realmente encontrando igual força de persuasão tanto no discurso eleata quanto no aristotélico, para dar um exemplo, e suspendeu o juízo sobre ambos, alegando seguir os fenômenos sem acreditar em nenhum deles. Do mesmo modo que pode haver aquele filósofo que "sabe", a cada segundo, que o mundo é totalmente diferente do modo como ele lhe aparece, me parece que o cético de Sexto Empírico sabe, a cada segundo, que o mundo pode ser totalmente diferente do modo como ele lhe aparece. As anedotas sobre Pirro caindo em pântanos, abismos ou buracos talvez não sejam tolice e intriga da oposição, como gostava de dizer Porchat, mas apenas uma maneira que o pioneiro do ceticismo teria encontrado para ensinar os seus discípulos a serem verdadeiros "afrontadores das crenças comuns".

É bastante conhecida a anedota sobre o cínico Diógenes segundo a qual, ao ouvir os argumentos de Zenão contra a existência do movimento, teria se levantado e saído (na versão de Simplício), ou se levantado e andado (na versão de Diógenes Laércio). Circula, nos meios céticos brasileiros, uma versão alternativa da anedota, da qual não encontrei amparo nas fontes, e que dá um final diferente para a versão de Diógenes Laércio. A ouvi pela primeira vez da boca de Plínio Smith, mas Porchat a conhecia já que me lembro de conversar mais de uma vez sobre ela com ele. Diz a lenda que após o grande mestre cínico se levantar e andar, supostamente refutando os argumentos de Zenáo, um de seus discípulos o teria aplaudido e exclamando "parabéns, mestre, o senhor refutou Zenão", ao que Diógenes teria se dirigido a ele e desferido um tapa na em sua cara. $\mathrm{Na}$ interpretação neopirrônica da versão alongada da anedota, o sábio Diógenes de Sínope teria ensinado ao seu discípulo, com um tapa na cara, que ele não havia refutado coisa alguma, que Zenão obviamente estava ciente que o movimento 
aparecia para todos, mas que não era disso que Zenão estava falando, pois o que Zenão estava discutindo estava para além do que aparece, era uma interpretação do fenômeno. Os fenômenos seriam, para Porchat, formas de crenças céticas muitas vezes compartilhadas por kantianos e berkeleyanos, e seria "ridículo e esdrúxulo", e "uma demonstração de espantosa ingenuidade filosófica" (Porchat, 2006, p.134-5), invocar esses fenômenos contra o imaterialismo de Berkeley ou contra a doutrina de Kant e, por que não, contra o imobilismo de Zenão.

Se Diógenes na versão neopirrônica da anedota dá o tapa na cara do discípulo admirado, reprimindo-o por julgar que o mero fato de que o movimento é fenômeno serve de alguma coisa para o embate com o imobilismo, prefiro uma segunda versão fictícia dessa história, a de um Diógenes de inspiração pirrônica ortodoxa que, ao ouvir os argumentos de Zenão contra o movimento, levantou e andou, lembrando a todos que o movimento se nos impóe, pahinetai, brilha, aparece-nos fortemente, e que sua existência é, por assim dizer, provável, isto é, pitanè, estamos tentados a nos persuadir dela. E quando um de seus discípulos exclamou "bravo, mestre, o senhor refutou o imobililismo de Zenão", Diógenes se dirigiu a ele e lhe deu um tapa, passando a parafrasear, passo a passo, toda a argumentação imobilista, lembrando-lhe não do absurdo que seria uma refutação deste tipo, mas, ao contrário, da força do lógos, que, quando bem elaborado, praticamente arrebata os fenômenos da nossa frente. E opondo o fenômeno do movimento aos argumentos imobilistas, suspendeu o juízo sobre a sua existência ou inexistência.

Identificar o pirronismo antigo com qualquer forma de desprezo pela ontologia me parece distanciar o intérprete do sentido original do ceticismo de Sexto, Agrippa e Enesidemo. Porque a manutenção de uma suspensão do juízo sobre tudo frequentemente precisa se servir de uma gigantomaquia sobre o ser, bem como de várias das outras discussões fundamentais da filosofia.

\section{Referências Bibliográficas}

Heidegger, M. (20I2). Ser e tempo. Campinas: Editora da Unicamp.

Porchat, O. (2006). Rumo ao Ceticismo. São Paulo: Editora Unesp.

Porchat, O. (20I3). A noção de phainómenon em Sexto Empírico. Analytica, Rio de Janeiro, v.I7, n.2, p. 29I-323.

Schvartz, V. H. (20I5). "Porchat, sua interpretação de Sexto, e um possível neopirronismo rústico", in: Silva Filho, W. J.; Smith, P. J. (ed.). Oswaldo Porchat: Interpretaçóes e debate. São Paulo: Alameda Editorial. p. I8I-204.

Sexto Empírico (1976). Sextus Empiricus in four volumes (v.r: Outlines of pyrrhonism; v. 2-4: Adversus Mathematicos VI-XI). Loeb Classical Library. Cambridge/Massachussetts/ London: Harvard University Press. 